Genetics and Molecular Biology, 27, 2, 199-206 (2004)

Copyright by the Brazilian Society of Genetics. Printed in Brazil

www.sbg.org.br

Research Article

\title{
The genetics of tolerance to tristeza disease in citrus rootstocks
}

\author{
Rita Bordignon ${ }^{1}$, Herculano Penna Medina-Filho ${ }^{1}$, Walter José Siqueira ${ }^{2}$ and Joaquim Teófilo Sobrinho ${ }^{3}$ \\ ${ }^{1}$ Instituto Agronômico (IAC), Centro de Análise e Pesquisa do Agronegócio do Café Alcides Carvalho, \\ Campinas, SP, Brazil. \\ ${ }^{2}$ Instituto Agronômico (IAC), Centro de Pesquisa e Desenvolvimento de Recursos Genéticos Vegetais, \\ Campinas, SP, Brazil. \\ ${ }^{3}$ Instituto Agronômico (IAC), Centro Avançado de Pesquisa Tecnológica do Agronegócio de Citros \\ Sylvio Moreira, Cordeirópolis, SP, Brazil.
}

\begin{abstract}
Controlled pollinations between four elite citrus rootstocks, Citrus limonia - 'Limeira' rangpur lime (Cravo), C. sunki 'Sunki' mandarin (Sunki), C. aurantium - 'São Paulo' sour orange (Azeda) and Poncirus trifoliata - 'Davis A' trifoliate orange (Trifoliata), resulted in 1614 nucelar and 1938 hybrid plants identified by the isozyme loci Pgi-1, Pgm-1, Got-1, Got-2, Aps-1, Me-1, Prxa-1 and or by the morphological markers broadness of leaf petiole wing or trifoliolate leaves. Tolerance to the citrus tristeza virus (CTV) was evaluated under nursery and field conditions for several years by the reaction of Valencia orange infected with a severe strain of CTV and grafted onto the hybrids and nucellar clones. Genetic analyses indicated that tolerance was controlled by at least two loci designated here as $A z$ and $t$ interacting in dominant-recessive epistasis. Genotypes $A z \_\ldots$ _ and _ _ $t$ t were tolerant while azaz $T$ _ was intolerant. The intolerant Azeda was azaz TT, the tolerant rootstocks Sunki and Cravo were Azaz tt and the Trifoliata was Azaz TT. The different degrees of intolerance seen in some hybrids may reflect the inability of segregating modifiers from parental clones to overcome the epistatic interaction that controls the major tolerance reaction.
\end{abstract}

Key words: Citrus, CTV, epistasis, rootstock, tristeza.

Received: January 6, 2003; Accepted: October 21, 2003.

\section{Introduction}

Compared to other plant diseases, citrus tristeza disease has received little attention in Brazil in recent years, despite its enormous historical importance and the economic threat that it still represents to other countries (Lee et al., 1992; Yokomi et al., 1994; Gottwald et al., 1994, 1998; Rocha-Peña et al., 1995; Hughes and Gottwald, 2001; Riac, 2001; Hughes et al., 2002; Stover and Castle, 2002). To a large extent, this lack of interest reflects the success of agricultural research in this country in dealing with this disease since the late 1940s (Franco and Bacchi, 1944; Meneghini, 1946), but is also related to the characteristics and mode of transmission of the disease (Bitancourt and Rodrigues Filho, 1948; Bennett and Costa, 1949; Bitancourt, 1954). In addition, extensive tests with several hundred introduced rootstocks in diverse scion combinations of oranges, mandarins, limes and lemons have resulted in practical solutions and efficient measures to control this disease (Moreira

Send correspondence to R. Bordignon. Instituto Agronômico (IAC), Centro de Análise e Pesquisa do Agronegócio do Café Alcides Carvalho, Caixa Postal 28, 13001-970 Campinas, SP, Brazil. E-mail: rita@iac.sp.gov.br. et al., 1949, 1954; Moreira and Salibe, 1969; Pompeu Junior, 1990). As a result, all of the sweet orange crop in Brazil, which accounts for $75 \%$ of the world's production, and $20 \%$ of the concentrated juice on the international market, derive from orchards established with rootstocks tolerant to the citrus tristeza virus (CTV) (Informativo Centro de Citricultura, 2002), a long RNA virus that damages plant phloem (Kitajima et al., 1964). The characteristics and symptoms of tristeza disease, and its implications for the scion/rootstock relationship have been discussed in detail by Costa et al. (1949), Müller (1976), Adams (1991), Lee et al. (1994) and Bordignon et al. (2003).

Tolerance to CTV is seen in the ability of rootstock phloem to withstand the presence of the virus without adverse effects on normal cellular and physiological functions. Tolerance, as defined here, is distinct from the resistance seen in several Citrus and related species in which there is no multiplication and movement of the virus within the plant (Moreira et al., 1949; Yoshida, 1993; Mestre et al., 1997a,b). CTV is abundant in susceptible scions, such as sweet oranges, mandarins, limes and grapefruits (Moreira et al., 1954). Since CTV occurs in all 
susceptible commercial scion sources in Brazil, and since the widespread distribution of the brown citrus aphid (Toxoptera citricida), the most efficient vector of CTV, means that no virus-free plants remain uninfected in any orchard, the use of tolerant rootstocks is essential, preferably together with tolerant scions.

For several decades, the rangpur lime (Citrus limonia), commonly known in Brazil as "limão Cravo" (referred to here simply as Cravo) has been the most widely used tolerant rootstock (Pompeu Junior, 1990), although there is concern about the need for rootstock diversification. Other species with tolerance to blight and trunk gummosis could also be useful in reducing the biological vulnerability of the crop to disease. During a breeding program at the Instituto Agronômico (IAC), thousands of controlled pollinations among elite rootstocks were done to obtain hybrids with desirable agricultural and industrial characteristics derived from different genitors. Tolerance to tristeza, the principal criterion for selection, was also evaluated in these hybrids. This tolerance is effective against all forms of CTV complexes (mild, regular, severe) responsible for symptoms such as quick-decline, leaf rolling, seedling yellows and stunting. Such CTV complexes have produced epidemics of tristeza in sweet oranges grafted onto sour oranges in major producing areas of the world. However, this tolerance is not effective against the Capão Bonito strains of CTV, to which the Rangpur lime is intolerant, or to the stem-pitting strains of xylem CTV complexes that affect scions, regardless of the rootstocks.

Based on the reaction of some hybrids imported from the USA, Costa et al. (1949) suggested that tolerance was a dominant characteristic, but did not examine this phenomenon any further. In this study, the reaction to CTV of 1614 nucellar plants and 1938 hybrids from four genitors was investigated in order to determine the genetic control of tolerance to the tristeza disease in citrus rootstocks.

\section{Materials and Methods}

\section{Plant material}

The genitors used in the crosses were from the Sylvio Moreira CAPTAC germplasm collection held at the IAC station in Cordeirópolis. These genitors (identifications used in the text are indicated in parenthesis) were: Poncirus trifoliata 'Davis A' - trifoliate orange, 848-Q.30 (Trifoliata or T), Citrus limonia - 'Limeira' rangpur lime, 863-Q.30 and Banco de Matrizes (Cravo or C), Citrus sunki - 'Sunki' mandarin, 200-Q.57, Coleção Clones Velhos and Banco de Matrizes (referred to as Sunki or S), Citrus aurantium 'São Paulo' sour orange, 244-Coleção Clones Velhos and 285-Q.16 (Azeda or A).

\section{Controlled crosses and hybrid production}

Two series of controlled crosses were done in consecutive years (Series I and II) by emasculation, protection and pollination of more than 5,000 flowers. The mucilage, testa and integument were removed from the seeds of mature fruits and the seeds then germinated in moist Petri dishes. The embryos were subsequently removed from each seed and transplanted to seedling trays. The technique used in the crosses and in subsequent procedures have been described in detail elsewhere (Bordignon et al., 1990; Bordignon, 1995). The results of the following crosses were studied: T x A, S x A, A x S, C x A, A x C, T x S, S x T, S x C and $\mathrm{C} \times \mathrm{S}$.

Identification of hybrids and nucellar clones based on the isozyme profile, the presence of trifoliolate leaves and the broadness of the leaf petiole wing

After transplanting, the seedlings were subjected to isozyme analyses and/or were evaluated for leaf markers to identify hybrids and maternal nucellar clones.

Plants from the crosses A x C, C x A, A x S, S x A were analyzed mainly by the broadness of the leaf petiole wing (Ballvé et al., 1997); doubtful cases were by isozyme analysis or were discarded. The dominant trifoliolate leaf marker (Toxopeus, 1962) was used to identify S x T hybrids.

Horizontal starch gel electrophoresis was used to identify the hybrids of T x A, T x S, C x S and S x C crosses (Ballvé et al., 1991 1995). The PGI (phosphoglucoisomerase), PGM (phosphoglucomutase), GOT (glutamate oxaloacetate transaminase), PRX (peroxidase), ME (malic enzyme) and APS (acid phosphatase) enzymatic systems were screened to determine the genotype for the Pgi-1, Pgm-1, Got-1, Got-2, Prxa-1, Me-1 and Aps-1 loci.

\section{Orange grafts and setting up of COS I and COS II plots}

COS I and II, plots for observation and selection, were established using hybrid and nucellar clones from the crosses of series I and II, respectively. In COS I plot, the plants were transplanted to plastic bags in the nursery and bud grafted with Valencia sweet orange infected with a severe CTV strain. After eight months, the seedlings were pruned back and transplanted to the field in the spacing $8 \mathrm{x}$ 4 meters. COS I consisted of 138 nucellar plants (48 Cravo, 48 Sunki, 9 Azeda, 33 Trifoliata) and 534 hybrids (65 T x A, 48 C x A, 20 T x S, 67 S x T, $207 \mathrm{~S} \times$ C, 98 S x A and 29 C $\mathrm{x}$ S). For COS II, seedlings from the seedling trays were transplanted directly to the field and grafted with the same Valencia budwood as COS I. Because of the large number used, the seedlings were planted in double $1 \times 0.5 \mathrm{~m}$ rows, $3 \mathrm{~m}$ apart. This plot consisted of 1410 nucellar clones (429 Cravo, 410 Sunki, 571 Azeda) and 1413 hybrids (845 S x A, $240 \mathrm{~A} x \mathrm{~S}, 139 \mathrm{C} \times \mathrm{A}, 19 \mathrm{~A} \times \mathrm{C}, 147 \mathrm{~S} \times \mathrm{C}$ and $23 \mathrm{C} \times \mathrm{S})$.

\section{Evaluations and observations in the nursery and in the COS I plot}

Nursery plants from series I crosses were rated according to their general development and health conditions, 
leafiness, leaf rolling, presence of seedling yellows and stunting. These parameters were also recorded in 1996, 1997, 1998 and 1999 in the field. Scion diameter was evaluated in 1996 and 2000, rootstock diameter in 1996, 1998 and 2000, canopy diameter in 1998 and 2000, plant height in 1998 and 2000, vigor index [calculated from the original measurements, in centimeters, as: plant height + canopy diameter $+($ rootstock diameter x 10)/100] in 1998 and 2000, mean fruit weight (based on a maximum of 10 fruits/plant) in 1997, 1998 and 1999, and yield in 1997, 1998 and 1999. In 2000, all these parameters were consolidated into a single tristeza index that varied from 1 to 7 and reflected the intensity of the symptoms, with 7 being the most severe.

\section{Evaluations and observations in the COS II plot}

In COS II, the reaction of the hybrids and genitors to tristeza was initially evaluated six months after the Valencia clone had budded on the rootstocks. The plants were scored on three occasions for seedling yellows and stunting, whereas scion diameter was measured once. Based on these data, the hybrids were classified as tolerant or intolerant by comparison with the maternal nucellar progenies of the genitors.

\section{Statistical analysis}

Statistical comparisons were done with the chi-square $\left(\chi^{2}\right)$ test calculated using MINITAB software. Yates' correction for continuity (Little and Hills, 1978; Snedecor and Cochran, 1967) was applied because the segregations consisted of only two classes and one degree of freedom. A value of $\mathrm{p}<0.05$ indicated significance.

\section{Results and Discussion}

\section{Tolerance to tristeza disease}

The intensity of the tristeza symptoms in COS I varied from 1 to 7 , with 7 corresponding to plants with the most extreme manifestation of intolerance, such as conspicuous seedling yellows, stunting, no yield or a yield limited to the production of a few small fruits. The intensity of the symptoms was not the same for all intolerant plants, as also reported by Costa et al. (1949) during early studies of the disease. For this reason, in the final classification, plants that scored higher than 2 were considered intolerant. This apparently rigid criterion was adopted because all 128 plants in the tolerant Cravo, Sunki and Trifoliata groups had scores of 1 or 2, and also because the Valencia scion is considered to be quite a tolerant clone. In the nursery, all 76 Azeda plants showed typical symptoms of seedling yellows and reduced growth, although the intensity was somewhat variable. The nine most vigorous plants of this group were transplanted to the field but, as expected, they soon stopped growing, became stunted, or died after producing a few small fruits; they all received a score of 7. The S x A, C x A, T x A, T x S and S x T hybrids yielded typically healthy, tol- erant plants with scores of 1 or 2 , as well as intolerant plants. The reactions of the Valencia orange grafted onto tolerant and intolerant rootstocks are shown in Figure 1. A1though all plants from the nucellar Azeda rootstock invariably showed extreme symptoms of intolerance (score 7), hybrids of this stock also showed less severe symptoms (scores of 3 to 6). Plants with such scores were classified as intolerant because even with their less intense symptoms, their level of intolerance precluded any future attempt to select them. Additionally, the Valencia orange is more tolerant to tristeza than other well-established clones such as Pera. Most of the individuals in the field, and all of the Azeda nucellars and class 7 hybrids, were carefully checked for stem-pitting at the scion-stock junction, but none was found, despite the general occurrence of such at this site (Figueiredo et al., 1993).

The classification criterion for the COS II plot was less elaborate. The field was established with plants taken directly from the greenhouse trays and planted close together. This resulted in stressful conditions in which seedling yellows and stunting were more common (Figure 1). Comparison of the scion diameter of intolerant hybrids and Azeda with those of tolerant hybrids and of Sunki and Cravo indicated that there was reduced growth in intolerant plants compared to tolerant ones in both fields (Table 1). In COS II, plants with seedling yellows, small rolled leaves, stunting and or with diameters $<2 \mathrm{~cm}$ were considered intolerant. All grafts onto Sunki and Cravo were healthy, the leaves were a normal dark green, and more than $95 \%$ of 839 plants had diameters $>2 \mathrm{~cm}($ mean $=3.4 \mathrm{~cm})$, while all 571 plants grafted onto Azeda had seedling yellows and related symptoms, as well as a diameter $<2 \mathrm{~cm}$, (mean $=0.86 \mathrm{~cm})$. Overall, the reaction to tristeza seen in both fields agreed fully with the expected tolerance of Cravo, Sunki and Trifoliata and with the intolerance of Azeda. Tolerant and intolerant individuals were observed among the hybrids, as discussed below.

\section{The genetics of tolerance}

Table 2 shows the number of tolerant and intolerant individuals among the parental plants and their hybrids in the COS I and COS II plots. In addition to the data in Table 2 , any attempt to unravel the genetic control of tolerance must contemplate the following considerations:

a) The tolerance of Trifoliata, Sunki, Cravo, the Sunki $\mathrm{x}$ Cravo hybrids and their reciprocals is unquestionable, as is the absolute intolerance of Azeda.

b) There is genetic segregation between the Azeda hybrids and the tolerant Sunki, Cravo and Trifoliata $(\sim 1: 1)$ and between Trifoliata $x$ Sunki and their reciprocals ( $\sim 3: 1)$.

c) Selfing of Sunki and Cravo yielded only tolerant plants among the zygotic seedlings, as deduced from the observation that in commercial nurseries the frequency of zygotics is $5-15 \%$ (H.P. Medina Filho, R. Bordignon, un- 

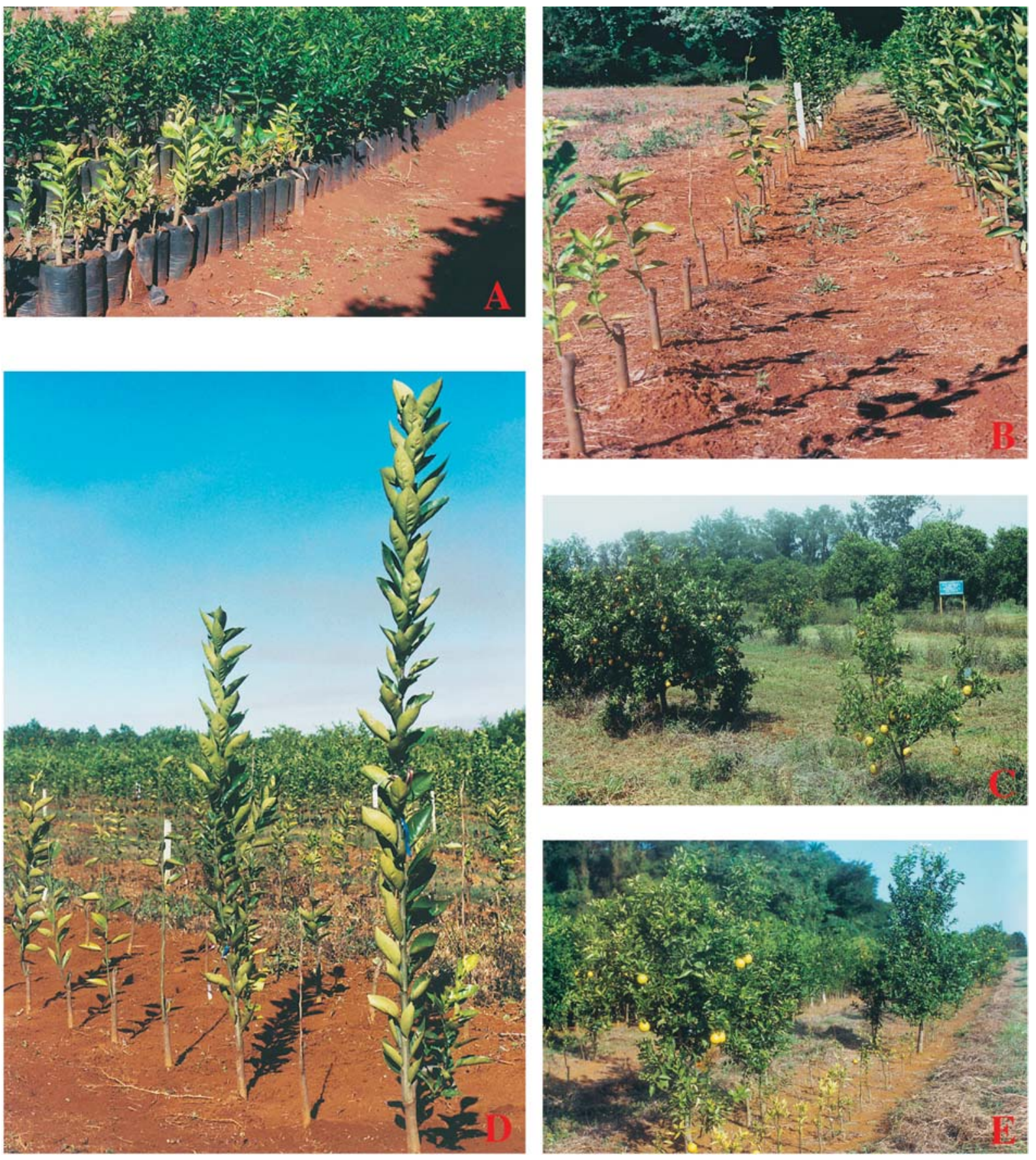

Figure 1 - Valencia orange scions grafted onto Azeda (intolerant) in the nursery before transplanting to the COS I plot (A) and in the plot COS II (B). The plants on the left show extreme symptoms of intolerance to tristeza (seedling yellows - score 7) when compared with tolerant plants (scores 1 and 2). When grafted onto segregating hybrids in $\operatorname{COS~I~(C)~and~COS~II~(D~and~E),~there~was~a~conspicuous~reduction~in~plant~vigor~in~the~intolerant~hybrids.~}$

published data) and the fact that no symptoms of tristeza were seen in grafted plants.

d) The selfing of Azeda yielded only intolerant plants, as shown by the fact that since the 1930 s, when tristeza was introduced into Brazil and infected 10 million trees grafted onto Azeda, intensive efforts have been made to find toler- ant individuals with the excellent qualities of Azeda as a rootstock. Although millions of trees have been investigated (many of which were certainly of zygotic origin), not a single tolerant individual has been found, neither in Brazil nor in any other citrus-growing region of the world. Invariably, all of the putative exceptions proved to be escapes, 
Table 1 - Mean scion diameter $(\mathrm{cm})$ for Valencia orange grafted onto Azeda (A), Trifoliata (T), Sunki (S), Cravo (C) and their hybrids segregating for tolerant $(\mathrm{t})$ and intolerant (i) hybrids to tristeza, and the corresponding percentage reduction in this parameter in intolerant hybrids in COS I and II plots in 1998. The COS I and COS II plots contained 633 and 2823 plants, respectively. $\mu=$ average.

\begin{tabular}{|c|c|c|c|c|c|c|}
\hline & \multicolumn{3}{|c|}{ COS I } & \multicolumn{3}{|c|}{ COS II } \\
\hline & i & $\mathrm{t}$ & $\%$ reduction & $\mathrm{i}$ & $\mathrm{t}$ & $\%$ reduction \\
\hline A & 2.7 & & & 0.83 & & \\
\hline $\mathrm{T}$ & & 7.3 & & & & \\
\hline S & & 9.2 & & & 3.5 & \\
\hline $\mathrm{C}$ & & 9.4 & & & 3.0 & \\
\hline TxA & 4.3 & 7.4 & 42 & & & \\
\hline SxA & 5.1 & 8.7 & 41 & 0.98 & 3.4 & 71 \\
\hline CxA & 5.1 & 8.0 & 36 & 0.69 & 2.4 & 71 \\
\hline TxS & 5.0 & 9.0 & 45 & & & \\
\hline SxT & 4.4 & 8.5 & 48 & & & \\
\hline $\mathrm{SxC}$ & & 8.9 & & & 2.7 & \\
\hline $\mathrm{CxS}$ & & 8.5 & & & 2.3 & \\
\hline AxS & & & & 0.72 & 3.2 & 78 \\
\hline $\mathrm{AxC}$ & & & & 0.81 & 2.6 & 69 \\
\hline$\mu$ genitors & 2.7 & 8.6 & 68 & 0.83 & 3.25 & 74 \\
\hline$\mu$ hybrids & 4.8 & 8.4 & 43 & 0.8 & 2.8 & 71 \\
\hline
\end{tabular}

Table 2 - Reaction to tristeza disease. Number (n) of tolerant (t) and intolerant (i) plants in the genitors Trifoliata (T), Sunki (S), Cravo (C), Azeda (A) and their hybrids scored in the plots COS I and COS II. The observed and expected ratios, the Chi-square $\left(\chi^{2}\right)$ values (corrected for continuity) and the corresponding probabilities (in percent) are also shown. The values for COS II plots are shown in bold italics.

\begin{tabular}{lccccccc}
\hline & $\begin{array}{c}\text { Scored plants } \\
\mathrm{N}\end{array}$ & $\begin{array}{c}\text { Tolerant } \\
\mathrm{t}\end{array}$ & $\begin{array}{c}\text { Intolerant } \\
\mathrm{i}\end{array}$ & $\begin{array}{c}\text { Observed } \\
\mathrm{t}: \mathrm{i}\end{array}$ & $\begin{array}{c}\text { Expected } \\
\mathrm{t}: \mathrm{i}\end{array}$ & $\chi^{2}$ & $\begin{array}{c}\mathrm{P} \\
\%\end{array}$ \\
\hline $\mathrm{T}$ & 33 & 33 & 0 & $\mathrm{t}$ & $\mathrm{t}$ & & \\
$\mathrm{S}$ & 48 & 48 & 0 & $\mathrm{t}$ & $\mathrm{t}$ & & \\
& $\mathbf{4 1 0}$ & $\mathbf{4 1 0}$ & $\mathbf{0}$ & $\boldsymbol{t}$ & $\boldsymbol{t}$ & & \\
$\mathrm{C}$ & 47 & 47 & 0 & $\mathrm{t}$ & $\mathrm{t}$ & & \\
& $\mathbf{4 2 9}$ & $\mathbf{4 2 9}$ & $\mathbf{0}$ & $\boldsymbol{t}$ & $\boldsymbol{t}$ & & \\
$\mathrm{A}$ & $\mathbf{7 6}$ & 0 & 76 & $\mathrm{i}$ & $\mathrm{i}$ & & \\
& $\mathbf{5 7 1}$ & $\mathbf{0}$ & $\mathbf{5 7 1}$ & $\boldsymbol{i}$ & $\boldsymbol{i}$ & & \\
$\mathrm{SxA}$ & 103 & 60 & 43 & $1.39: 1$ & $1: 1$ & 2.81 & 7.9 \\
& $\mathbf{8 4 5}$ & $\mathbf{5 2 3}$ & $\mathbf{3 2 2}$ & $\mathbf{1 . 6 2 : 1}$ & $\mathbf{1 : 1}$ & $\mathbf{4 7 . 8 1}$ & $\mathbf{0}$ \\
$\mathrm{AxS}$ & $\mathbf{2 4 0}$ & $\mathbf{1 1 8}$ & $\mathbf{1 2 2}$ & $\mathbf{1 : 1 . 0 3}$ & $\mathbf{1 : 1}$ & $\mathbf{0 . 0 6 7}$ & $\mathbf{1 0 0}$ \\
$\mathrm{CxA}$ & 49 & 27 & 22 & $1.23: 1$ & $1: 1$ & 0.327 & 100 \\
& $\mathbf{1 3 9}$ & $\mathbf{7 8}$ & $\mathbf{6 1}$ & $\mathbf{1 . 2 8 : 1}$ & $\mathbf{1 : 1}$ & $\mathbf{1 . 8 4}$ & $\mathbf{1 5 . 3}$ \\
$\mathrm{AxC}$ & $\mathbf{1 9}$ & $\mathbf{1 0}$ & $\mathbf{9}$ & $\mathbf{1 . 1 1 : 1}$ & $\mathbf{1 : 1}$ & $\mathbf{0 . 0 0}$ & $\mathbf{1 0 0}$ \\
$\mathrm{TxA}$ & 53 & 21 & 32 & $1: 1.52$ & $1: 1$ & 1.89 & 15.3 \\
$\mathrm{TxS}$ & 24 & 16 & 8 & $2: 1$ & $3: 1$ & 0.50 & 100 \\
$\mathrm{SxT}$ & 60 & 44 & 16 & $2.75: 1$ & $3: 1$ & 0.02 & 100 \\
$\mathrm{SxC}$ & 207 & 207 & 0 & $\mathrm{t}$ & $\mathrm{t}$ & & \\
& $\mathbf{1 4 7}$ & $\mathbf{1 4 7}$ & $\boldsymbol{0}$ & $\boldsymbol{t}$ & $\boldsymbol{t}$ & & \\
$\mathrm{CxS}$ & 29 & 29 & 0 & $\mathrm{t}$ & $\mathrm{t}$ & & \\
& $\mathbf{2 3}$ & $\mathbf{2 3}$ & $\boldsymbol{0}$ & $\boldsymbol{t}$ & $\boldsymbol{t}$ & & \\
\hline
\end{tabular}

hybrids or misnomers (Müller, 1976; Castle et al., 1989; Müller et al., 1990). A tolerant accession from China, known as Gou-Tou-Chen and that is under observation at the IAC station in Cordeirópolis, is also of hybrid origin
(Castle et al., 1989; Müller et al., 1990) as confirmed by a close inspection of its fruits and isozyme profiles (H.P. Medina Filho, R. Bordignon, G.W. Müller, unpublished data). 
Careful analysis of the genetic mechanism of tolerance indicated that no hypothesis based on quantitative inheritance or on the action of a single gene or two or more loci acting without epistasis could account for all of the data in Table II and for considerations a), b), c), and d) above. Among several known interacting systems (Sinnott and Dunn, 1939; Grant, 1975; Strickberger, 1976), a plausible alternative is the so-called dominant-recessive epistasis model that involves two loci, designated here as $A z$ and $t$, that control the tolerance of the plant to CTV. Thus, the intolerant genotypes would be $a z a z T_{-}$, while the tolerant ones would be $A z_{-}{ }_{-}$and _-_ $t$ t. Thus, the intolerant Azeda would be azaz $T \bar{T}$, the tolerant Sunki and Cravo would be Azaz $t$ and Trifoliata would be Azaz TT.

Based on this reasoning, the selfing of Azeda would produce only intolerant zygotic progenies of the azaz TT genotype, while that of Sunki and Cravo would yield only tolerant plants (Azaz tt and $a z a z t t)$, and Trifoliata would yield tolerant ( $A z A z T T, A z a z T T)$ and intolerant (azaz TT) plants in a 3:1 ratio [see also points (c) and (d) above].

There is no information about the reaction of zygotic progenies of selfed Trifoliata to tristeza that would make it easy to check the heterozygous Azaz TT nature of this clone. However, this heterozygous nature is certain since crosses with Azeda ( $a z a z T T)$ resulted in tolerant ( $A z a z T T)$ and intolerant (azaz TT) hybrids that were produced in an approximately 1:1 ratio. Additionally, the $\mathrm{T} \times \mathrm{S}$ hybrids and reciprocals that would be $A z A z T t$ and $A z a z T t$ tolerant and azaz $T t$ intolerant, respectively, in a theoretical ratio of 3:1, actually occurred in ratios of 2:1 and 2.8:1 (Table 2). Furthermore, other hybrids of $P$. trifoliata are referred to as tolerant or intolerant (Costa et al., 1949), which reinforces the conclusion that Trifoliata Davis A used here is heterozigous.

Crosses of Cravo or Sunki with Azeda (Azaz tt x azaz $T T$ ) would be expected to result in a 1:1 segregation of $A z a z$ $T t$ tolerant and azaz $\mathrm{Tt}$ intolerant progeny. Indeed, the segregations observed were close to this value (1.1-1.6:1; $\chi^{2}$ not significant in 3 out of 6 crosses; Table 2$)$. In the case of Cravo x Sunki (Azaz tt x Azaz tt), segregation would occur for $A z a z$, but not for $t$, thus resulting in only tolerant hybrids, exactly as observed.

The present model of epistasis qualitatively explains the tristeza reaction seen in the four genitors, in their selfed zygotic progenies and in nine hybrid combinations studied in COS I and COS II plots. Follow-up investigations with selected $\mathrm{F}_{2}$ progeny, additional crosses, and QTL analysis (Tanksley et al., 1982) of these populations would help to explain the genetic differences among individuals with different degrees of intolerance. The segregation of modifier loci could be one explanation since the major epistatic interaction conditioning the main tolerance reaction is not overcome.

Another aspect to be considered concerns segregations that partially deviate from the theoretically expected ratios of tolerant:intolerant individuals. A possible reason for this could be pre-zygotic selection and unequal viability of embryos, particularly if one considers the interspecific and the intergeneric nature of the crosses. Another possible source of distortion in the segregations could be the differential transmission of alleles as a result of meiotic irregularities, a common feature of interspecific hybrids. In this regard, it is possible that Cravo might not be a bona fide species, as judged by the fact that it is referred to as a lemon in Brazil, a lime in the USA, India and China, and a mandarin-like taxon (Hodgson, 1967), in addition to being classified as $C$. reticulata (a mandarin species) by Swingle and Reece (1967) and C. limonia by Tanaka (1954), the latter in allusion to its resemblance to lemons. In a recent study (Medina Filho et al., 2003), the segregation of isozyme alleles in the genitors of these hybrids showed marked distortion in the transmission of alleles of three Cravo isozyme loci. However, such observations does no alter the conclusions concerning the genetics of tolerance to tristeza addressed here.

\section{Conclusions}

The results of this investigation show that tolerance to tristeza disease, i.e., the ability of phloem tissue to tolerate $\mathrm{CTV}$, is conditioned by at least two loci, $A z$ and $t$, interacting in a dominant-recessive epistasis. Plants with the genotypes $A z_{-}{ }_{-}$and _ $t t$ are tolerant and those with $a z a z T_{\text {, }}$ intolerant. The intolerant Azeda ('São Paulo' sour orange) is azaz TT while the tolerant Sunki mandarin and Cravo ('Limeira' rangpur lime) are $A z a z t t$ and Trifoliata ('Davis A' trifoliate orange) is Azaz TT. Different levels of intolerance could be the result of segregation of modifier loci.

\section{Acknowledgments}

The authors thank G.W. Müller for identifying the tristeza symptoms, J. Pompeu Junior for suggestions, and R.M.L. Ballvé, M.R.T. Carvalho, S.L.S. Lima and D. Naves for help at various stages during this work. R.B. and H.P.M.F. were supported by CAPES and CNPq fellowships, respectively.

\section{References}

Adams JT (1991) Reviewing the latest on citrus tristeza virus. Citrus Industry 7:68-73.

Ballvé RML, Bordignon R, Medina Filho HP, Siqueira WJ, Teófilo Sobrinho J and Pompeu Junior J (1991) Isoenzimas na identificação precoce de híbridos e clones nucelares no melhoramento de citros. Bragantia 50:57-76.

Ballvé RML, Medina Filho HP and Bordignon R (1997) Identification of reciprocal hybrids in citrus by the broadness of the leaf petiole wing. Braz J Genet 20:697-702.

Ballvé RML, Medina Filho HP, Bordignon R and Lima MMA (1995) Methodology for starch gel electrophoresis and protocols for isozymes of 32 plant genera. Braz J Genet 18:441-502. 
Bennett CW and Costa AS (1949) Tristeza disease of citrus. J Agric Res 78:207-237.

Bitancourt AA (1954) Estudos sobre a tristeza dos citrus. 3. Experiências de transmissão. Arch Inst Biol 21:57-64.

Bitancourt AA and Rodrigues Filho AJ (1948) Estudos sobre a tristeza dos citrus. 1. Análise estatística da distribuição das árvores doentes de um pomar de laranjeira-doce enxertadas sobre laranjeira-azeda. Arch Inst Biol 18:313-338.

Bordignon R (1995) Hibridações interespecíficas, intergenéricas, intergrupais, intersubtribais, intertribais e intersubfamiliares de Citrus e gêneros relacionados. MSc Thesis, Universidade Estadual de Campinas, Campinas.

Bordignon R, Medina Filho HP, Müller GW and Siqueira WJ (2003) A tristeza dos citros e suas implicações no melhoramento genético de porta-enxertos. Bragantia 62:345-355.

Bordignon R, Medina Filho HP and Ballvé RML (1990) Melhoramento genético de citros no Instituto Agronômico. Laranja 11:167-176.

Castle WS, Tucker DPH, Krezdorn AH and Youtsey CO (1989) Rootstock selection: The first step to success. In: Cooperative Extension Service, Rootstocks for Florida Citrus. University of Florida, Institute of Food and Agricultural Science, Gainesville, 47 pp.

Costa AS, Grant TJ and Moreira S (1949) Investigações sobre a tristeza dos Citrus II. Conceitos e dados sobre a reação das plantas cítricas à tristeza. Bragantia 9:59-80.

Figueiredo JO, Pompeu Júnior J, Pio RM, Müller GW and Teófilo Sobrinho J (1993) Estudos recentes sobre a ocorrência de caneluras da tristeza em variedades de citros. Laranja 14:329-339.

Franco CM and Bacchi O (1944) Investigações sobre a tristeza dos citrus. Bragantia 4:541-551.

Gottwald TR, Garnsey SM and Borbón J (1998) Increase and patterns of spread of citrus tristeza virus infections in Costa Rica and the Dominican Republic in the presence of the brown citrus aphid, Toxoptera citricida. Phytopathology 88:621-636.

Gottwald TR, Garnsey SM and Yokomi RK (1994) Present distribution of citrus tristeza virus and its vector, the brown citrus aphid, and the potential for further spread. Citrus Industry 3:52-63.

Grant V (1975) Genetics of Flowering Plants. Columbia University Press, New York, 514 pp.

Hodgson RW (1967) Horticultural varieties of Citrus. In: Reuther W, Webber HJ and Batcherlor LD (eds) The Citrus Industry. v. 1. University of California Press, Riverside, pp 431-591.

Hughes G and Gottwald TR (2001) Survey methods for assessment of citrus tristeza virus incidence in citrus nurseries. Plant Dis 85:910-918.

Hughes G, Gottwald TR and Yamamura K (2002) Survey methods for assessment of citrus tristeza virus incidence in urban citrus populations. Plant Dis 86:167-172.

Informativo Centro de Citricultura (2002) Quem é quem na citricultura mundial. Centro de Citricultura, Cordeirópolis, $\mathrm{n}$. $87,4 \mathrm{p}$.

Kitajima EW, Silva DM, Oliveira AR, Müller GW and Costa AS (1964) Thread-like particles associated with tristeza disease of citrus. Nature 201:1011-1012.

Lee RF, Baker PS and Rocha-Peña MA (1994) The Citrus Tristeza Virus (CTV). International Institute of Biological Control, Ascot, 145 pp.
Lee RF, Roistacher CN, Niblett CL, Lastra R, Rocha-Peña M, Garnsey SM, Yokomi RK, Gumpf DG and Dodds JA (1992) Presence of Toxoptera citricidus in Central America: a threat to citrus in Florida and the United States. Citrus Industry 6:13-63.

Little TM and Hills FJ (1978) Agricultural Experimentation. Design and Analysis. John Wiley and Sons, Santa Barbara, 350 pp.

Medina Filho HP, Bordignon R and Siqueira WJ (2003) Segregações gaméticas de locos isoenzímicos em porta-enxertos de citros e suas contribuições alélicas na formação de híbridos. Bragantia 62:357-367.

Meneghini M (1946) Sobre a natureza e transmissibilidade da doença tristeza dos Citrus. O Biológico 12:285-287.

Mestre PF, Asins MI, Carbonell EA and Navarro L (1997a) New gene(s) involved in the resistance of Poncirus trifoliata (L.) Raf. to citrus tristeza virus. Theor Appl Genet 95:691-695.

Mestre PF, Asins MI, Pina JA and Navarro L (1997b) Efficient search for new resistant genotypes to the citrus tristeza closterovirus in the orange subfamily Aurantioideae. Theor Appl Genet 95:1282-1288.

Moreira S, Costa AS and Grant TJ (1949) Conhecimentos atuais sobre a tristeza dos citrus. Revista de Agricultura 24:335345 .

Moreira S, Costa AS and Grant TJ (1954) Métodos para identifícação e controle da tristeza dos citros. Bragantia 13:223241.

Moreira S and Salibe AA (1969) The contribution of research for the progressive changes in citrus rootstocks for South America. Proceedings of First International Citrus Symposium, v. 1. Riverside, CA, pp 351-357.

Müller GW (1976) A tristeza dos citros. Summa Phytopathologica 2:245-263.

Müller GW, Costa AS and Pompeu Júnior J (1990) Importância do porta-enxerto em relação à tristeza e outras moléstias dos citros no Brasil. Anais do I Seminário Internacional de Citros, Bebedouro, Brazil, pp 223-231.

Pompeu Júnior J (1990) Situação do uso de porta-enxertos no Brasil. Anais do I Seminário Internacional de Citros, Bebedouro, Brazil, pp 1-10.

RIAC-Red Interamericana de Cítricos (2001) Carta Circular. Instituto de Investigaciones de Cítricos y otros Frutales, La Habana, n. 18, 42 pp.

Rocha-Peña MA, Lee RF, Lastra R, Niblett CL, Ochoa-Corona FM, Garnsey SM and Yokomi K (1995) Citrus tristeza virus and its aphid vector Toxoptera citricida. Plant Dis 79:437445.

Sinnott EW and Dunn LC (1939) Principles of Genetics. 3rd ed. McGraw-Hill, New York, 408 pp.

Snedecor GW and Cochran WG (1967) Statistical Methods. 6th ed. Iowa State University Press, Iowa, 593 pp.

Stover E and Castle W (2002) Citrus rootstock usage, characteristics and selection in the Florida Indian River region. HortTechnology 12:143-147.

Strickberger MW (1976) Genetics. 2nd ed. MacMillan, New York, $914 \mathrm{pp}$.

Swingle WT and Reece PC (1967) The botany of Citrus and its wild relatives. In: Reuther W, Batcherlor LD and Webber WJ (eds) The Citrus Industry. v. 1. University of California Press, Riverside, pp 190-430. 
Tanaka T (1954) Species problem in Citrus (Revisio aurantianarum). Jpn Soc Promot Sci 1, 152 pp.

Tanksley SD, Medina Filho HP and Rick CM (1982) Use of naturally-occurring enzyme variation to detect and map genes controlling quantitative traits in an interspecific backcross of tomato. Heredity 49:11-25.

Toxopeus H (1962) Notes on the genetics of a few leaf characters in the genus Citrus. Euphytica 11:19-25.
Yokomi RK, Lastra R, Stoetzel MB, Damsteegt VD, Lee RF, Garnsey SM, Gottwald TR, Rocha-Peña MA and Niblett CL (1994) Establishment of the brown citrus aphid (Homoptera: Aphididae) in Central America and in the Caribbean basin and transmission of citrus tristeza virus. J Econ Entomol 87:178-185.

Yoshida T (1993) Inheritance of immunity to citrus tristeza virus of trifoliate orange in some citrus intergeneric hybrids. Bull Fruit Tree Res Station 25:33-43.

Editor Associado: Márcio de Castro Silva Filho 